\title{
Statistics Communication Document
}

National Cancer Institute

\section{Source}

National Cancer Institute. Statistics Communication Document. NCI Thesaurus. Code C115731.

Records pertaining to communications about statistics used in a clinical trial. 